\title{
急性尿閉症例の臨床的検討
}

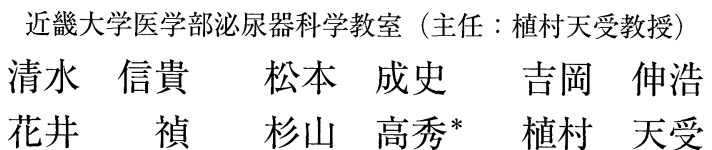

\section{CLINICAL STUDY OF ACUTE URINARY RETENTION}

\author{
Nobutaka Shimizu, Seiji Matsumoto, Nobuhiro Yoshioka, Tadashi Hanai, \\ Takahide Sugiyama and Hirotsugu Uemura \\ From the Department of Urology, Kinki University School of Medicine
}

(Purpose) Clinical study of acute urinary retention seen by this department.

(Materials and Methods) Subjects were 206 cases seen during office hours and during afterhours emergency care by the department of Urology at the Kinki University Hospital for acute urinary retention for the 12-year-period from April 1993 to April 2005.

(Results) By gender, the 206 cases of acute urinary retention included 175 men (85\%) and 31 women (15\%). The ratio of men to women was $5.6: 1$, with a markedly larger number of male cases. Ages of the 206 cases overall were distributed from 6 to 93 years old and the mean age was 66 years old. In male cases, the mean age was 69.6 years old while in female cases it was 46.3 years old. With regard to the cause, bladder outlet obstruction (BOO) accounted for $123(70.3 \%)$ of the 175 male cases; benign prostatic hyperplasia (BPH) was noted in 92 cases and accounted for $52.6 \%$ of the total. Detrusor Weakness (DW) was noted in 35 cases (20\%). DW was most prevalent in women, being noted in 20 cases $(64.5 \%)$. With regard to treatment, in male cases surgery was performed for BOO in $69(56 \%)$ of 123 cases ; surgery was performed for $\mathrm{BPH}$ in $56(60.8 \%)$ of 92 cases, drug therapy was used in 19 cases, and 3 cases were observed. In female cases, 10 cases were able to urinate on their own through treatment of the causative disorder. With regard to outcome, ultimately a total of 139 cases (67.5\%), 125 men and 14 women, were able to urinate on their own.

(Conclusions)

1. $85 \%$ of acute urinary retention cases were men. Of these, $70 \%$ were caused by some form of BOO. DW due to a cause other than obstruction accounted for about $70 \%$ of the remaining $30 \%$.

2. Overall, $70 \%$ of cases were able to urinate on their own after treatment while $30 \%$ required catheterization.

3. After the cause of BOO was eliminated, cases were likely to be able to urinate on their own ; CIC (clean intermittent catheterization) was frequently used in treatment of causes other than BOO.

4. $15 \%$ of acute urinary retention cases were women.

Key words : acute urinary retention, Bladder Outlet obstruction, Detrusor weakness

要旨：(目的）当科を受診した急性尿閉に対する臨床的検討を行った.

（対象と方法） 1993 年 4 月から 2005 年 4 月までの 12 年間に, 急性尿閉にて近畿大学医学部泌尿器科 を診療時間内および救急診療時間帯に受診した 206 症例を対象とした.

（結果）急性尿閉症例 206 症例の性別は男性 175 例 (85\%), 女性 31 例 (15\%)であった. 男女比は $5.6: 1$

*現 高石藤井病院 
で男性に著明に多く認めた. 206 症例全体の年齢分布は最少 6 歳から最高 93 歳に分布し平均 66 歳で あった. 男性例では平均 69.6 歳であった. 女性例では平均 46.3 歳であった. 原因疾患は男性では下部尿 路閉塞 (Bladder Outlet Obstruction; BOO) が 175 例中 123 例（70.3\%）を占め, その中でも前立腺肥大 症（Benign Prostatic hyperplasia ; BPH）が 92 例と全体の $52.6 \%$ を占めた．排尿筋収縮力低下（Detrusor Weakness；DW）は 35 例（20\%）であった．女性では DW が 20 例（64.5\%）で最も多かった．治療 は男性例では BOO 123 例中 69 例 (56\%) に手術療法を行い, 中でも BPH には 92 例中 56 例 (60.8\%) に 手術治療, 19 例に薬物治療, 3 例で経過観察を行った. 女性例では 10 例で原因疾患の治療により自排尿 が可能となった. 転帰は, 最終的に自排尿が可能になったのは男性 125 例, 女性 14 例の計 139 例 (67.5\%) であった.

(結論)

1 急性尿閉の $85 \%$ は男性. そのうち $70 \%$ は何らかの BOO に起因する. 残る $30 \%$ は閉塞ではない原 因により DW は約 70\% を占めた.

2 全体で治療後約 $70 \%$ が自排尿可能となったが $30 \%$ はカテーテル手技を要した.

3 BOOの原因解除で自排尿となる可能性が高いがBOO以外の原因の治療ではCICが高率であった.

4 急性尿閉の $15 \%$ は女性であった.

キーワード : 急性尿閉, 下部尿路閉塞, 排尿筋収縮力低下

\section{緒言}

排尿障害の一つである尿閉は泌尿器科医が遭遇する 機会の多い症候であり，また日常の診療の中で緊急の 処置を行わなければならない場合も多い. さらに尿閉 が一旦軽快した後も継続して追加治療を要する症例も ある．尿閉をきたす疾患の主たるものは前立腺肥大症 などの下部尿路閉塞であり, 発生頻度は圧倒的に男性 に多い. しかし臨床の場では若年症例や女性症例も見 受けられ, 必ずしも尿閉の原因が下部尿路閉塞だけに 限らないといえる。部尿路閉塞として扱った症例の 中にも排尿筋収縮力低下を伴う場合も多いと思われ, 原因によってその後の治療における方針が全く異なる ため, 排尿機能を評価する各種の検査を引き続き行う ことが必要と考えられる。

今回われわれは, 過去 12 年間に当科を受診した急性 尿閉症例を集計し, 後ろ向き臨床的検討を行ったので 報告する。

\section{対象と方法}

1993 年 4 月から 2005 年 4 月まで 12 年間に, 急性尿 閉にて近畿大学医学部泌尿器科を診療時間内および救 急診療時間帯に受診した 206 症例を対象とした.この 206 症例について, 性差, 年齢分布, 原因疾患, 治療, 転帰等について臨床的検討を行った．急性尿閉とは, 突然排尿が不可能となり導尿が必要な状態を指す1). ここでの BOO とは何らかの原因で下部尿路が閉塞し た状態を指し，DW は尿流量測定や残尿測定等のウ口 ダイナミックスパラメーターを元に主治医が診断した ものをDWと表現した. 全例 pressure flow study
(PFS) を施行しているわけではなく, 尿閉後 3〜4 週間 で尿流量測定や残尿測定で判断したものが大半である (尿閉後の 3 週間以内の膀胱内圧測定は正確な膀胱機 能を反映しないとされる ${ }^{2)}$ ，原因不明とは，明らかな BOO や DW を伴わず, 薬物, 手術等の明らかな誘因の ないものとした。また BPH と神経因性膀胱（Neurogenic bladder;NGB）の混合例においては全例 PFS を施行しており, BOO の要素が強い症例では BOO, DW の要素が強い症例では DW とした.これらを元に 後ろ向き検討を行った.

\section{結 果}

\section{1. 男女比}

急性尿閉症例 206 症例の性別は男性 175 例 (85\%), 女性 31 例 (15\%) であった。男女比は $5.6: 1$ で男性に 著明に多かった。

\section{2. 年齢分布}

206 症例全体の年齢分布は最少 6 歳から最高 93 歳 に分布し平均 66 歳であった。男性例では 6 歳から 93 歳にわたり平均 69.6 歳であった（Fig. 1).女性例では 7 歳から 77 歳にわたり平均 46.3 歳であった (Fig. 2). 男性例では 60 歳以上の症例が 175 例中 149 例と全体 の $85.1 \%$ を占め, その中でも 70 歳代が 68 例と最も多 かったのに対し, 女性例では 40 歳未満の症例が 31 例 中 14 例で $45.2 \%$ を占めた.

3. 原因疾患

1）男性例（Table 1)

BOO が 175 例中 123 例（70.3\%）を占め，その中で も $\mathrm{BPH}$ が 92 例と全体の $52.6 \%$ を占めた. DW が 35 
Fig. 1 Age distribution of acute urinary retention in men.

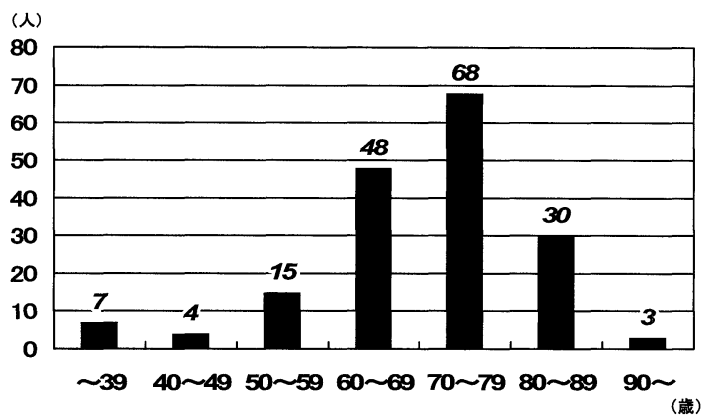

Fig. 2 Age distribution of acute urinary retention in women.

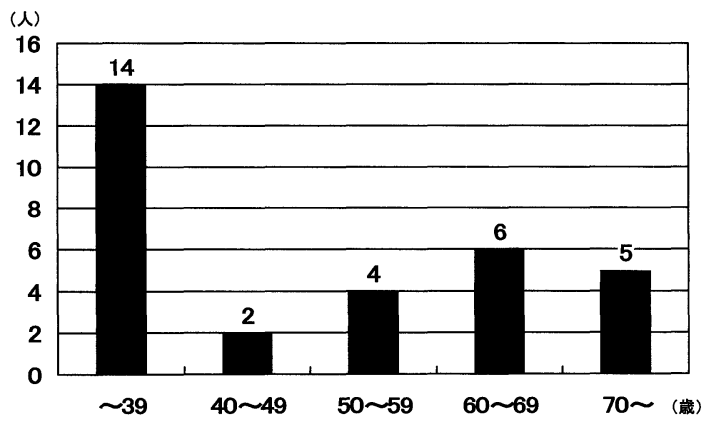

例 $(20 \%)$ であった．次いで前立腺癌 12 例 $(6.9 \%)$, 尿道狭窄 8 例 $(4.6 \%)$ の順で多く認められた.

平均前立腺重量は $\mathrm{BOO}$ 症例（BOO $>\mathrm{DW}$ 症例を含 む) で $38.7 \mathrm{~g}(10 \sim 84.6 \mathrm{~g} / 72$ 例 $), \mathrm{DW}$ 症例 (DW $>\mathrm{BOO}$ 症例を含む）で $15.8 \mathrm{~g}$ (8～ $22.2 \mathrm{~g} / 10$ 例 $)$ であった.

2）女性例 (Table 2)

DW が 20 例 $(64.5 \%)$ で最も多く，次いで原因不明 4 例 (12.9\%)，心因性 3 例 $(9.6 \%)$ の順に多かった. ほかに術後(尿路, 骨盤内手術を除く), 子宮筋腫があった.

今回女性においてはBOO が原因と考えられた症 例は子宮筋腫の 2 例であった.

\section{4. 既往歴}

急性尿閉の既往のある症例は 27 例（13.1\%）であっ た. 男性例では BOO が 123 例中 17 例 (13.8\%)で, DW が 35 例中 5 例（14.2\%）であった．女性例では全 31 例中 DW の 4 例，原因不明の 1 例，薬㘊性 1 例，放射 線性膀胱炎 1 例で認めた．特にBOOに尿閉の既往が 多いというわけではなかった。 また排尿に関する治療 歴がある症例は, 男性例 BOO では 123 例中 59 例と約
Table 1 Etiology of acute urinary retention in 175 men.

\begin{tabular}{|c|c|c|}
\hline 下部尿路閉塞 & 123 例 & $(70.3 \%)$ \\
\hline $\mathrm{BPH}$ & 92 例 & $(52.6 \%)$ \\
\hline 前立腺癌 & 12 例 & $(6.9 \%)$ \\
\hline 尿道狭窄 & 8 例 & $(4.6 \%)$ \\
\hline 膀胱頸部硬化症 & 2 例 & $(1.1 \%)$ \\
\hline 包茎 & 3 例 & $(1.7 \%)$ \\
\hline 下部尿路術後 & 3 例 & $(1.7 \%)$ \\
\hline 尿道結石 & 3 例 & $(1.7 \%)$ \\
\hline 排尿筋収縮力低下 & 35 例 & $(20.0 \%)$ \\
\hline 薬荗性 & 7 例 & $(4.0 \%)$ \\
\hline $\begin{array}{l}\text { 上記以外の排尿筋 } \\
\text { 収縮力低下 } / \mathrm{NGB}\end{array}$ & 28 例 & $(16.0 \%)$ \\
\hline その他 & 9 例 & $(5.1 \%)$ \\
\hline 膀胱夕ンポナーデ & 6 例 & $(3.4 \%)$ \\
\hline 術後 (骨盤内手術以外) & 3 例 & $(1.7 \%)$ \\
\hline 不明 & 8 例 & $(4.6 \%)$ \\
\hline
\end{tabular}

Table 2 Etiology of acute urinary retention in 31 women.

\begin{tabular}{|c|c|c|}
\hline 排尿筋収縮力低下 & 20 例 & $(64.5 \%)$ \\
\hline 薬剤性 & 5 例 & $(16.1 \%)$ \\
\hline ヘルペス（慰部，陰部） & 2 例 & $(6.4 \%)$ \\
\hline 放射線性膀胱炎 & 1 例 & $(3.2 \%)$ \\
\hline 脊髄炎 & 1 例 & $(3.2 \%)$ \\
\hline 脊髄梗塞 & 1 例 & $(3.2 \%)$ \\
\hline $\begin{array}{l}\text { 上記以外の排尿笳収縮 } \\
\text { 力低下 } / \mathrm{NGB}\end{array}$ & 10 例 & $(32.2 \%)$ \\
\hline その他 & 7 例 & $(22.6 \%)$ \\
\hline 心因性 & 3 例 & $(9.6 \%)$ \\
\hline 術後 (骨盤内手術以外) & 2 例 & $(6.5 \%)$ \\
\hline 子宮筋腫 & 2 例 & $(6.5 \%)$ \\
\hline 不明 & 4 例 & $(12.9 \%)$ \\
\hline
\end{tabular}

半数であるのに対し, DW では男性例 35 例中 15 例, 女性例 20 例中 1 例と少なかった.

5. 治療

急性尿閉時には全例一時的もしくは持続的なカテー テル操作による導尿を行った。男性例では BOO, 123 例中 69 例に手術療法を行い, 中でも $\mathrm{BPH}$ には 92 例 中 56 例 $(60.8 \%)$ に手術治療，19例に薬物治療，3 例で経過観察を行い自排尿が可能となった. BPH に対 する手術治療の方法は経尿道的前立腺切除術（TURP) が 43 例と最も多く約半数を占め, 次いで経尿道的 
Fig. 3 Outcome of the patients.

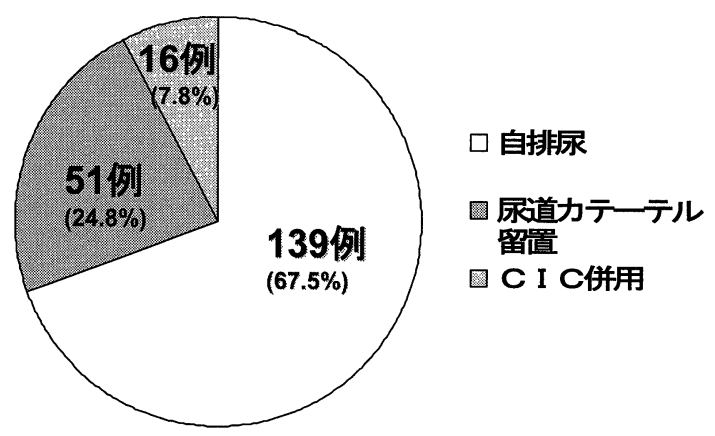

前立腺高温度治療 (TUMT) 4 例, 恥骨後式前立腺摘除 術 (RPP) 3 例, 尿道ステント留置 4 例, V-LAP 2 例で ある. DW に対しては 35 例中薬物治療で 7 例, 経過観 察で 2 例自排尿可能となった. 女性例では DW の 4 例 で自排尿が可能となり，2例が薬物療法, 1 例が CIC 後数力月で, 1 例が経過観察で自排尿が可能となった. その他の 7 例は原因疾患の治療で自排尿が可能にな り, 不明例 3 例も最終的に自排尿が可能になった.

6. 転帰 (Fig. 3)

最終的に自排尿が可能になったのは男性 125 例, 女 性 14 例の計 139 例（67.5\%）であり, BOO では 123 例 中 99 例 $(80.4 \%)$, DW では男性 35 例中 9 例 (25.7\%)，女性 20 例中 4 例（20\%）であった. CIC を引き続き要したのは男性 13 例, 女性 3 例の計 16 例 (7.7\%)で, また膀胱留置バルーンカテーテルによる管 理が必要になったのは男性 37 例, 女性 14 例の計 51 例 $(24.8 \%)$ であった. DW 症例は BOO に比べると CIC や膀胱留置カテーテルに頼る場合が多かった.

\section{考察}

急性尿閉は突然排尿が不可能となり導尿が必要な状

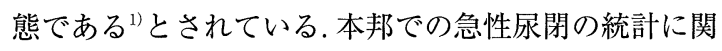
する報告は少ない3 ${ }^{3}$. その罪患率は男性 45 歳以上で 1 年間に 1,000 人当たり 2.2 人とされ, 下部尿路症状や $\mathrm{BPH}$ を持つものは 1 年間に 1,000 人当たり 18.3 人と 高率になる ${ }^{1)}$. また, 1 年間に 1,000 人当たり $5 \sim 25$ 人 で年齢の増加と共に罹患率が上昇し, 60 歳以下ではま れで, 70 歳代では 40 歳代に比べ 8 倍の危険があると いう報告もある ${ }^{4 / 5)}$. 今回我々は, 12 年間の全受診患者 を算出することが出来ず罹患率は示せないが, 急性尿 閉症例 206 症例のうち $85 \%$ を男性例が占め, 70 歳代 で最も多く認められる事が分かった。

その中でも $\mathrm{BPH}$ を主とする $\mathrm{BOO}$ に起因するもの
が約 70\% を占めるため, その好発年齢である高齢男性 に頻度が高い. しかし一方で残る約 $30 \%$ の症例は BOO ではない原因で尿閉をきたしており，その約 $70 \%$ DW が占め尿閉の原因が必ずしも BOO に限 らないことが分かった。

Murray K らによると 2 年間に大学病院を受診した 急性尿閉 310 例の原因を調査したところ, BPH が $53 \%$, 次いで便秘が $7.5 \%$, 前立腺癌が $7 \%$, 尿道狭窄 が $3.5 \%$, 凝血塊が $3 \%$, 神経障害, 術後, 結石, 薬剂 性, 感染がそれぞれ $2 \%$ で, 不明が $16 \%$ ありこれらを 見ても必ずしも尿閉の原因が BOO に限らない事がわ かる ${ }^{6)}$.

急性尿閉は一般的に 3 つのカゴリーに分けられて いる.1）下部尿路閉塞すなわち機械的閉塞によるもの, 2) 膀胱の知覚もしくは運動神経の障害によるもの（薬 剂などが含まれる $\left.)^{7} ， 3\right)$ 全身麻酔後に最も見られる膀 胱の過伸展や $\alpha$-adrenergic tone が尿道括約筋の収縮 力を増加させる事である ${ }^{5 / 8)}$. 今回の検討では不明例を 除けばすべてこのカテゴリーに含まれた。

また圧倒的に男性が多いが女性例も約 15\% は存在 しており，日常診療においてはしばしば遭遇する。男 性例とは異なり 40 歳代未満の症例が約半数を占めた. 女性例の原因に精神科関連の薬剤によるものや心因性 のものが多く含まれているためと考えられる.

Klarskov P らによると女性の急性尿閉の䍜患率は 1 年間に 10 万人あたり 7 人と報告している9．女性にお ける急性尿閉の主な病因は術後, 膀胱炎, 膀胱下から の解剖学的な圧迫, 排尿筋機能の低下, 婦人科疾患, ヒステリックによるものとされている ${ }^{10)}$. 今回の原因 疾患では NGB や薬哓等の原因による排尿筋収縮力低 下がほとんどであったが, Turner-Warwick らの報告 では膀胱炎や外部からの圧迫による閉塞が主な要因の ようである ${ }^{10)}$.この違いは，本邦でも膀胱炎や外部か らの圧迫による閉塞で排尿障害はあると考えられる が，急性尿閉には至らず，その前段階で治療がなされ ているためと考える，今回，外部からの圧迫による閉 塞すなわち BOO が原因と考えられた症例は子宮筋腫 の 2 例であった.

急性尿閉に対する処置は導尿もしくは恥骨上穿刺で ある. 今回恥骨上穿刺した症例はなかったが, 緊急処 置を行ったうえで原因治療に移ることとなる，興味の あるところは, カテーテル留置期間についてである. 今回は後ろ向き検討のため, 詳しい留置期間等は検討 できなかったが, Djavan B らは，急性尿閉になった患 
者を 3 つのグループに分けカテーテル抜去時期で再カ テーテル率について検討しており，(1)導尿のみ(2)2 日 留置(3)7 日留置の 3 群に分けたところ, 再カテーテル 率は(1)56\%(2)49\%(3)38\% という結果であった。 また, IPSS, 前立腺重量, 血清 PSA 等との関連性はないが, 75 歳以下， 尿閉時の尿量が $1,000 \mathrm{ml}$ 以下，最大排尿筋 圧が $35 \mathrm{cmH}_{2} \mathrm{O}$ 以上であればカテーテルを抜去しても 問題ないとしている ${ }^{11}$ ．留置期間が長いほど再カテー テル率は低いようである。 また，Lucas MG らは BPH 患者の急性尿閉に対して Tamsulosin を用いてカテー テル抜去後の再カテーテル回避率を検討している ${ }^{4)}$. これによれば, 141 人の急性尿閉の患者に導尿後， 71 名に Tamsulosin $(0.4 \mathrm{mg} /$ 日)，70 名に placebo を内服 させたところ, Tamsulosin 群では再カテーテルが 37 人 $(52 \%)$, placebo 群では 52 人 $(74 \%)$ であった。 $\alpha$ blocker は急性尿閉患者の再カテーテル回避に有効の ようである ${ }^{12) ~ 14) . ~}$

治療は, BOO 症例では 123 例中 69 例に手術治療を 行っており BPHに限れば 92 例のうち 56 例と約 6 割 で外科的治療を行った. Emberton M らは, BPH 患者 の場合，急性尿閉を起こした症例で約半数が手術に移 行したと報告しており ${ }^{15)}$ ，また急性尿閉は絶対的な手 術適応とも考えられている ${ }^{16)}$.

高齢化社会にあって, 急性尿閉は今後ともさらに増 加すると考えられ, BPH 症例では全身状態がよければ 積極的に手術を施行することがカテーテルフリーに繋 がると考えられる。 また $\alpha$-blocker が急性尿閉を回避 する 1 つの手段となることから, 積極的な投与でカ テーテルフリーに繋がると考えられる。

女性においては急性尿閉の主な要因は排尿筋機能の 低下であり，各々の原因治療が優先される，女性にお いても内診や外陰部の診察は不可欠であり，女性尿閉 患者の約半数は再発するという報告 ${ }^{810)} も$ もり, 慎重な 評価が必要である．出来れば引き続き尿流量測定，残 尿測定を行い，可能ならば PFS，膀胱鏡等の評価も必 要と考える.

\section{結 語}

1 急性尿閉の $85 \%$ は男性. そのうち $70 \%$ は何らか の BOO に起因する. 残る $30 \%$ は閉塞ではない原因に よりDW は約 $70 \%$ を占めた.

2 全体で治療後約 $70 \%$ が自排尿可能となったが $30 \%$ はカテーテル手技を要した.

$3 \mathrm{BOO}$ の原因解除で自排尿となる可能性が高いが BOO 以外の原因の治療では CIC が高率であった.
4 急性尿閉の $15 \%$ は女性である.

\section{文献}

1) Verhamme KM, Dieleman JP, van Wijk MA, Bosch JL, Stricker BH, Sturkenboom MC : Low incidence of acute urinary retention in the general male population : the triumph project. Eur. Urol., 47, 494-498, 2005.

2) Dubey D, Kumar A, Kapoor R, Srivastava A, Mandhani A : Acute urinary retention : defining the need and timing for pressure-flow studies. Br. J. Urol., 88, 178-182, 2001.

3）絵鳩哲哉, 上村博司, 公平昭男 : 急性尿閉症例 110 例の検討. 泌尿器外科, 4, 1131-1133, 1991 .

4) Lucas MG, Stephenson TP, Nargund V : Tamsulosin in the management of patients in acute urinary retention from benign prostatic hyperplasia. Br. J. Urol., 95, 354-357, 2005.

5) Jacobsen SJ, Jacobson DJ, Girman CJ, Roberts RO, Rhodes T, Guess HA, Lieber MM : Natural history of prostatism : risk factors for acute urinary retention. J. Urol., 158, 481-487, 1997.

6) Murray K, Massey A, Feneley RC : Acute urinary retention-a urodynamic assessment. Br. J. Urol., 56, 468-473, 1984.

7) Pompeius R. : Detrusor inhibition induced from anal region in man. Acta. Chir. Scand. Suppl., 361, $1-54,1966$.

8) Waterhouse N, Beaumont AR, Murray K, Staniforth $\mathrm{P}$, Stone $\mathrm{MH}$ : Urinary retention after total hip replacement. A prospective study. J. Bone. Joint. Surg. Br., 69, 64-66, 1987.

9) Klarskov P, Andersen JT, Asmussen CF, Brenoe J, Jensen SK, Jensen IL, Lund P, Schultz A, Vedel $\mathrm{T}$ : Acute urinary retention in women : a prospective study of 18 consecutive cases. Scand. J. Urol. Nephrol., 21, 29-31, 1987.

10) Turner-Warwick R : Impaired voiding efficiency and retention. Clin. Obstet. Gynaecol., 5, 193-207, 1978.

11) Choong $S$, Emberton $M$ : Acute urinary retention. Br. J. Urol., 85, 186-201, 2000.

12) McNeill SA, Hargreave TB; Members of the Alfaur Study Group. : Alfuzosin once daily facilitates return to voiding in patients in acute urinary retention. J. Urol., 171, 2316-2320, 2004.

13) McNeill SA, Hargreave TB, Roehrborn CG ; Alfaur study group : Alfuzosin $10 \mathrm{mg}$ once daily in the management of acute urinary retention : results of a double-blind placebo-controlled study. Urology., 65, 83-89, 2005.

14) McNeill SA, Daruwala PD, Mitchell ID, Shearer MG, Hargreave TB : Sustained-release alfuzosin and trial without catheter after acute urinary retention : a prospective, placebo-controlled. Br. J. Urol., 84, 622-627, 1999.

15) Emberton $M$, Anson $K$ : Acute urinary retention in men : an age old problem. BMJ., 318, 921-925, 1999.

16) McConnell JD, Barry MJ, Bruskewitz RC : Benign prostatic hyperplasia: diagnosis and treatment. Agency for Health Care Policy and Research. Clin. Pract. Guidel. Quick. Re. f Guide. Clin., 8, 117, 1994.

(2005 年 6 月 7 日受付, 2006 年 4 月 19 日受理) 